\title{
PENGEMBANGAN BUDAYA DAN IKLIM SEKOLAH
}

\section{Oleh: Astuti \\ Dosen IAIN Bone}

\begin{abstract}
Abstrct: This paper discusses the development of school culture and climate. Conducive school climate and culture is characterized by the creation of a safe, comfortable, and orderly learning environment so that learning can take place effectively. Conducive school climate and culture are so important that learners feel happy and positive about their schools, so that teachers feel valued, and that parents and communities feel welcome and engage. This can happen through the creation of positive norms and habits, harmonious relationships and cooperation based on mutual respect. The school climate can basically be put forward as an organizational climate that occurs in a school. School climate is the result of interaction media in school organizations.
\end{abstract}

Keywords: Cultural development and school climate.

Pendidikan adalah salah satu pranata sosial yang menawarkan jasa layanan bersifat intelektual, afeksi, psikomotorik, emosional dan menyiapkan masa depan umat. Pendidikan juga merupakan investasi bagi setiap manusia (human investment) yang mampu mengantarkan manusia dalam memperkaya wawasan dan meningkatkan mutu hidup pada segala aspek kehidupan, terutama pembangunan dan pengembangan sumber daya manusia.

Sekolah sebagai lembaga pendidikan formal memerlukan manajemen yang efektif sehingga mampu mewujudkan budaya dan iklim yang kondusif. 


\section{A. Hakikat budaya dan Iklim Sekolah}

Budaya sekolah/madrasah merupakan bagian dari Budaya karporasi (corporate culture). Budaya karporat merupakan Budaya yang dibangun pada institusi atau lembaga yang dimiliki karakteristik tertentu. ${ }^{1}$

Beberapa hal yang menjadi ciri dari korporasi dikemukakkan oleh Kasali, sebagai berikut:

1. Terdapat pemisahan kekayaan (antara milik individu/keluarga/kelompok dengan milik organisasi sebagai badan hukum).

2. Pemisahan tanggung jawab, antara pemilik dan pelaksana.

3. Mengutamakan kepentingan pelanggan (customer satisfaction).

4. Bekerja dengan sistem.

5. Adanya pencatatan dan transparansi.

6. Adanya pertanggungjawaban (accountability).

7. Bergerak dengan strategi dan rencana kerja.

8. Adanya upaya regenerasi berkelanjutan. ${ }^{2}$

Budaya sekolah merupakan sesuatu yang dibangun dari hasil pertemuan antara nilai-nilai (values) yang dianut oleh kepala sekolah sebagai pemimpin dari nilai-nilai yang dianut oleh guru-guru dan para karyawan

${ }^{1}$ Muhaimin, Manajemen Pendidikan Aplikasinya dalam Menyusun Rencana Pengembangan Sekolah/Madrasah (Cet. 4; Jakarta: Fajar Interpratama Offeset, 2012), h.47. ${ }^{2}$ Ibid. 
yang ada dalam sekolah tersebut. Nilai-nilai tersebut dibangun oleh pikiranpikiran manusia yang ada dalam sekolah. Pertemuan pikiran-pikiran manusia tersebut kemudian menghasilkan apa disebut dengan "pikiran organisasi", ( Kasali). Dari pikiran-pikiran organisasi itulah kemudian muncul dalam bentuk nilai-nilai yang diyakini bersama, dan kemudian nilainilai tersebut akan menjadi bahan utama pembentuk budaya sekolah/sekolah. ${ }^{3}$

Iklim sekolah (school climate) pada dasarnya dapat dikemukakan sebagai iklim organisasi yang terjadi pada suatu sekolah. Iklim sekolah merupakan hasil dari media interaksi dalam organisasi sekolah. ${ }^{4}$ Iklim sekolah akan memberikan pengaruh pada prilaku guru dan tenaga kependidikan dalam melaksanakan tugasnya di sekolah.

Iklim dan budaya sekolah yang kondusif ditandai dengan terciptanya lingkungan belajar yang aman, nyaman, dan tertib, sehingga pembelajaran dapat berlangsung secara efektif. Iklim dan budaya sekolah yang kondusif sangat penting agar peserta didik merasa senang dan bersikap positif terhadap sekolahnya, agar guru merasa dihargai, serta agar orang tua dan masyarakat merasa diterima dan melibatka. Hal ini dapat terjadi melalui penciptaan norma dan kebiasaaan yang positif, hubungan dan kerjasama

${ }^{3}$ Ibid, h. 48. 129

${ }^{4}$ Dadang Suhardan, Supervisi Profesioonal (Cet, III; Bandung: Alfabeta, 2010), h. 
yang harmonis yang didasari oleh sikap saling menghormati. Selain itu, iklim dan budaya sekolah yang kondusif mendorong setiap warga sekolah untuk bertindak dan melakukan sesuatu yang terbaik yang mengarah pada prestasi peserta didik yang tinggi. ${ }^{5}$

\section{B. Faktor-faktor Penentu Iklim dan Budaya Sekolah}

Secara umum faktor-faktor Penentu yang perlu diperhatikan dalam iklim dan budaya sekolah sebagai berikut:

1. Tujuan dan sasaran pendidikan nasional dalam pembangunan bukan hanya untuk menciptakan golongan elit dan kaum intelektual, melainkan membentuk manusia Indonesia secara utuh melalui kegiatan bimbingan, pengajaran dan latihan bagi peranannya pada masa mendatang.

2. Peserta didik merupakan subjek sekaligus objek pendidikan. Perubahan perilaku peserta didik ditentukan oleh pengalaman belajarnya di samping faktor-faktor bawaan.

3. Mendidik merupakan pekerjaan profesional, memberikan petunjuk bahwa tidak setiap orang dapat melaksanakan profesi mendidik (pendidik).

${ }^{5}$ Mulyasa, Manajemen \& Kepemimpinan Kepala Sekolah (Cet.3; Jakarta: PT Bumi Aksara, 2013 ), h.90 
4. Isi pendidikan merupakan segala pengalaman yang harus dimiliki peserta didik sesuai dengan tujuan yang hendak dicapai melalui proses pendidikan.

5. Keberhasilan pendidikan sangat ditentukan oleh kelengkapan fasilitas dan sumber belajar. ${ }^{6}$

Adapun Faktor-faktor lain, Pembentuk Kebudayaan adalah sebagai berikut:

1. Pola pikir manusia yang terus berevolusi dalam memersepsi alam dan kehidupan

2. Pola hidup yang ditunjang oleh berbagai alat penunjang kehidupan

3. Pola tingkah laku yang diikat oleh nilai-nilai. ${ }^{7}$

\section{Fungsi Budaya Sekolah}

Ndraha mengemukakan, fungsi budaya sebagai berikut:

1. Identitas dan citra suatu masyarakat

2. Pengingat suatu masyarakat

3. Sumber inspirasi, kebanggaan, dan sumber daya

4. Kekuatan penggerak

5. Keemampuan untuk membentuk nilai tambah

6. Pola perilaku

${ }^{6} I b i d$, h. 104. h. 88 .

${ }^{7}$ Saefullah, Manajemen Pendidikan Islam (Cet.1; Bandung: Pustaka setia, 2012), 
7. Warisan

8. Pengganti formalisai

9. Mekanisme adaptasi terhadap perubahan. ${ }^{8}$

Budaya juga berfungsi sebagai mekanisme dan beradabtasi dengan berbagai perubahan yang terjadi, baik di dalam maupun di luar organisasi. Proses adaptasi tersebut dibutuhkan untuk menghindari terjadinya konflik antarbudaya. Mekanisme adaptasi menjadi ciri kedewasaan individu, kelompok, organisasi bahkan masyarakat negara tertentu. Dengan adaptasi, kehidupan dapat berjalan berjalan secara harmonis, tenteram aman dan damai. Karena esensi adaptasi sesungguhnya adalah saling menghargai kelebihandan kekurangan masing-masing. ${ }^{9}$

Dapat pula dikatakan bahwa budaya merupakan aset yang sangat berharga, yang dapat digunakan sebagai model dasar dalam membangun dan mengembangkan kehidupan berbangsa dan bernegara yang sejahtera, adil, dan bermartabat. ${ }^{10}$

\section{Model Pengembangan Budaya dan Iklim Sekolah}

Model pengembangan budaya dan iklim sekolah yang diharapkan dapat meningkatkan kualitas sumber daya manusia baik itu kepala sekolah, guru dan staf sekolah dan utamanya siswa itu sendiri dapat dijadikan dasar

\footnotetext{
${ }^{8}$ Ibid, h. 90.

${ }^{9}$ Ibid.

${ }^{10}$ Ibid.
} 
dalam upaya memperbaiki iklim sekolah. Model tersebut merupakan integrasi komponen-komponen seperti budaya sekolah, iklim organisasi, dan pranata sistem sekolah.

Komponen pengembangan budaya dan iklim sekolah secara umum dapat diklasifikasikan dalam tiga kategori dengan beberapa aspek sebagai berikut:

1. Budaya sekolah meliputi aspek-aspek:
a. Nilai
b. Norma
c. Perilaku

2. Lingkungan fisik sekolah meliputi:
a. Keindahan
b. Keamanan
c. Kenyamanan
d. Ketentraman
e. Kebersihan

3. Lingkungan sistem sekolah meliputi:
a. Berbasis mutu
b. Kepemimpinan kepala sekolah
c. Disiplin dan tata tertib
d. Penghargaan dan insentif 

e. Harapan untuk berprestasi
f. Akses informasi
g. Evaluasi
h. Komunikasi yang intensif dan terbuka ${ }^{11}$

\section{E. Prinsip-Prinsip Pengembangan Budaya dan Iklim Sekolah}

Prinsip adalah "suatu pernyataan atau suatu kebenaran yang pokok, yang memberikan suatu petunjuk kepada pemikiran atau tindakan. Lebih jauh dijelaskan pengertian prinsip yakni pedoman-pedoman yang dapat membantu dalam penerapan manajemen yang harus dipergunakan secara cermat dan bijaksana.

Budaya dan iklim sekolah yang efektif akan memberikan efek positif bagi semua unsur dan personil sekolah seperti kepala sekolah, guru, staf, siswa dan masyarakat. Prinsip-prinsip yang menjadi acuan dalam pengembangan budaya dan iklim sekolah adalah sebagai berikut.

\section{Berfokus Pada Visi, Misi dan Tujuan Sekolah}

Pengembangan budaya dan iklim sekolah harus senantiasa sejalan dengan visi, misi dan tujuan sekolah. Fungsi visi, misi, dan tujuan sekolah adalah mengarahkan pengembangan budaya dan iklim sekolah. Visi tentang keunggulan mutu misalnya, harus disertai dengan

\footnotetext{
${ }^{11}$ Departemen Pendidikan Nasional, Pengembangan Iklim dan Budaya pembelajaran di Sekolah, 2007, h. 15.
} 
program-program yang nyata mengenai penciptaan budaya dan iklim sekolah.

\section{Penciptaan Komunikasi Formal dan Informal}

Komunikasi merupakan dasar bagi koordinasi dalam sekolah, termasuk dalam menyampaikan pesan-pesan pentingnya budaya dan iklim sekolah. Komunikasi informal sama pentingnya dengan komunikasi formal. Dengan demikian kedua jalur komunikasi tersebut perlu digunakan dalam menyampaikan pesan secara efektif dan efisien.

\section{Inovatif dan Bersedia Mengambil Resiko}

Salah satu dimensi budaya organisasi adalah inovasi dan kesediaan mengambil resiko. Setiap perubahan budaya sekolah menyebabkan adanya resiko yang harus diterima khususnya bagi para pembaharu. Ketakutan akan resiko menyebabkan kurang beraninya seorang pemimpin mengambil sikap dan keputusan dalam waktu cepat.

\section{Memiliki Strategi yang Jelas}

Pengembangan budaya dan iklim sekolah perlu ditopang oleh strategi dan program. Startegi mencakup cara-cara yang ditempuh sedangkan program menyangkut kegiatan operasional yang perlu dilakukan. Strategi dan program merupakan dua hal yang selalu berkaitan.

\section{Berorientasi Kinerja}


Pengembangan budaya dan iklim sekolah perlu diarahkan pada sasaran yang sedapat mungkin dapat diukur. Sasaran yang dapat diukur akan mempermudah pengukuran capaian kinerja dari suatu sekolah.

\section{Sistem Evaluasi yang Jelas}

Untuk mengetahui kinerja pengembangan budaya dan iklim sekolah perlu dilakukan evaluasi secara rutin dan bertahap: jangka pendek, sedang, dan jangka panjang. Karena itu perlu dikembangkan sistem evaluasi terutama dalam hal: kapan evaluasi dilakukan, siapa yang melakukan dan mekanisme tindak lanjut yang harus dilakukan.

\section{Memiliki Komitmen yang Kuat}

Komitemen dari pimpinan dan warga sekolah sangat menentukan implementasi program-program pengembangan budaya dan iklim sekolah. Banyak bukti menunjukkan bahwa komitmen yang lemah terutama dari pimpinan menyebabkan program-program tidak terlaksana dengan baik.

\section{Keputusan Berdasarkan Konsensus}

Ciri budaya organisasi yang positif adalah pengembilan keputusan partisipatif yang berujung pada pengambilan keputusan secara konsensus. Meskipun hal itu tergantung pada situasi keputusan, 
namun pada umumnya konsensus dapat meningkatkan komitmen anggota organisasi dalam melaksanakan keputusan tersebut.

\section{Sistem Imbalan yang Jelas}

Pengembangan budaya dan iklim sekolah hendaknya disertai dengan sistem imbalan meskipun tidak selalu dalam bentuk barang atau uang. Bentuk lainnya adalah penghargaan atau kredit poin terutama bagi siswa yang menunjukkan perilaku positif yang sejalan dengan pengembangan budaya dan iklim sekolah.

\section{Evaluasi Diri}

Evaluasi diri merupakan salah satu alat untuk mengetahui masalahmasalah yang dihadapi di sekolah. Evaluasi dapat dilakukan dengan menggunakan pendekatan curah pendapat atau menggunakan skala penilaian diri. Kepala sekolah dapat mengembangkan metode penilaian diri yang berguna bagi pengembangan budaya dan iklim sekolah. Halaman berikut ini dikemukakan satu contoh untuk mengukur budaya dan iklim sekolah. ${ }^{12}$

\section{F. Asas-Asas Pengembangan Budaya dan Iklim Sekolah}

Definisi budaya dan iklim sekolah sebagaimana yang telah dijelaskan sebelumnya merupakan sebuah pola asumsi dasar dalam mengembangkan budaya dan iklim sekolah efektif, sehingga unsur dan prinsip-prinsipnya

\footnotetext{
${ }^{12}$ Ibid, h. 14-17.
} 
dianggap valid untuk dilaksanakan secara terus menerus serta diterapkan bukan hanya dianggap sebagai strategi tetapi lebih condong dipandang sebagai budaya. Oleh karena itu peningkatan mutu dan kualitas pendidikan di sekolah harus senantiasa dibarengi dengan pengembangan budaya dan iklim sekolah yang kondusif dengan menerapkan nilai-nilai dasar sebagai asas kehidupan sekolah.

Secara umum asas-asas pengembangan budaya dan iklim sekolah dapat diuraikan sebagai berikut:

\section{Kerjasama tim (team work)}

Pada dasarnya sebuah komunitas sekolah merupakan sebuah tim/kumpulan individu yang bekerja sama untuk mencapai tujuan. Untuk itu, nilai kerja sama merupakan suatu keharusan dan kerjasama merupakan aktivitas yang bertujuan untuk membangun kekuatankekuatan atau sumber daya yang dimilki oleh personil sekolah.

\section{Kemampuan}

Menunjuk pada kemampuan untuk mengerjakan tugas dan tanggung jawab pada tingkat kelas atau sekolah. Dalam lingkungan pembelajaran, kemampuan profesional guru bukan hanya ditunjukkan dalam bidang akademik tetapi juga dalam bersikap dan bertindak yang mencerminkan pribadi pendidik. 


\section{Keinginan}

Keinginan di sini merujuk pada kemauan atau kerelaan untuk melakukan tugas dan tanggung jawab untuk memberikan kepuasan terhadap siswa dan masyarakat. Semua nilai di atas tidak berarti apaapa jika tidak diiringi dengan keinginan. Keinginan juga harus diarahkan pada usaha untuk memperbaiki dan meningkatkan kemampuan dan kompetensi diri dalam melaksanakan tugas dan tanggung jawab sebagai budaya yang muncul dalam diri pribadi baik sebagai kepala sekolah, guru, dan staf dalam memberikan pelayanan kepada siswa dan masyarakat.

\section{Kegembiraan (happiness)}

Nilai kegembiraan ini harus dimiliki oleh seluruh personil sekolah dengan harapan kegembiraan yang kita miliki akan berimplikasi pada lingkungan dan iklim sekolah yang ramah dan menumbuhkan perasaan puas, nyaman, bahagia dan bangga sebagai bagian dari personil sekolah. Jika perlu dibuat wilayah-wilayah yang dapat membuat suasana dan memberi nuansa yang indah, nyaman, asri dan menyenangkan, seperti taman sekolah ditata dengan baik dan dibuat wilayah bebas masalah atau wilayah harus senyum dan sebagainya.

\section{Hormat (respect)}

Rasa hormat merupakan nilai yang memperlihatkan penghargaan kepada siapa saja baik dalam lingkungan sekolah maupun dengan stakeholders pendidikan lainnya. Keluhan-keluhan yang terjadi karena

perasaan tidak dihargai atau tidak diperlakukan dengan wajar akan menjadikan sekolah kurang dipercaya. Sikap respek dapat 
diungkapkan dengan cara memberi senyuman dan sapaan kepada siapa saja yang kita temui, bisa juga dengan memberikan hadiah yang menarik sebagai ungkapan rasa hormat dan penghargaan kita atas hasil kerja yang dilakukan dengan baik. Atau mengundang secara khusus dan menyampaikan selamat atas prestasi yang diperoleh dan sebagaianya.

\section{Jujur (honesty)}

Nilai kejujuran merupakan nilai yang paling mendasar dalam lingkungan sekolah, baik kejujuran pada diri sendiri maupun kejujuran kepada orang lain. Nilai kejujuran tidak terbatas pada kebenaran dalam melakukan pekerjaan atau tugas tetapi mencakup cara terbaik dalam membentuk pribadi yang obyektif. Tanpa kejujuran, kepercayaan tidak akan diperoleh. Oleh karena itu budaya jujur dalam setiap situasi dimanapun kita berada harus senantiasa dipertahankan. Jujur dalam memberikan penilaian, jujur dalam mengelola keuangan, jujur dalam penggunaan waktu serta konsisten pada tugas dan tanggung jawab merupakan pribadi yang kuat dalam menciptakan budaya dan iklim sekolah yang baik.

\section{Disiplin (discipline)}

Disiplin merupakan suatu bentuk ketaatan pada peraturan dan sanksi yang berlaku dalam lingkungan sekolah. Disiplin yang dimaksudkan dalam asas ini adalah sikap dan perilaku disiplin yang muncul karena kesadaran dan kerelaan kita untuk hidup teratur dan rapi serta mampu menempatkan sesuatu sesuai pada kondisi yang seharusnya. Jadi disiplin disini bukanlah sesuatu yang harus dan tidak harus dilakukan 
karena peraturan yang menuntut kita untuk taat pada aturan yang ada. Aturan atau tata tertib yang dipajang dimana-mana bahkan merupakan atribut, tidak akan menjamin untuk dipatuhi apabila tidak didukung dengan suasana atau iklim lingkungan sekolah yang disiplin. Disiplin tidak hanya berlaku pada orang tertentu saja di sekolah tetapi untuk semua personil sekolah tidak kecuali kepala sekolah, guru dan staf.

\section{Empati (empathy)}

Empati adalah kemampuan menempatkan diri atau dapat merasakan apa yang dirasakan oleh orang lain namun tidak ikut larut dalam perasaan itu. Sikap ini perlu dimiliki oleh seluruh personil sekolah agar dalam berinteraksi dengan siapa saja dan dimana saja mereka dapat memahami penyebab dari masalah yang mungkin dihadapai oleh orang lain dan mampu menempatkan diri sesuai dengan harapan orang tersebut. Dengan sifat empati warga sekolah dapat menumbuhkan budaya dan iklim sekolah yang lebih baik karena dilandasi oleh perasaan yang saling memahami.

\section{Pengetahuan dan Kesopanan}

Pengetahuan dan kesopanan para personil sekolah yang disertai dengan kemampuan untuk memperoleh kepercayaan dari siapa saja akan memberikan kesan yang meyakinkan bagi orang lain. Dimensi ini menuntut para guru, staf dan kepala sekolah tarmpil, profesional dan terlatih dalam memainkan perannya memenuhi tuntutan dan kebutuhan siswa, orang tua dan masyarakat. ${ }^{13}$

\footnotetext{
${ }^{13}$ Ibid, h.18-21.
} 


\section{G. Penutup}

Budaya sekolah merupakan sesuatu yang dibangun dari hasil pertemuan antara nilai-nilai (values) yang dianut oleh kepala sekolah sebagai pemimpin dari nilai-nilai yang dianut oleh guru-guru dan para karyawan yang ada dalam sekolah tersebut. Nilai-nilai tersebut dibangun oleh pikiranpikiran manusia yang ada dalam sekolah.

Iklim sekolah (school climate) pada dasarnya dapat dikemukakan sebagai iklim organisasi yang terjadi pada suatu sekolah. Iklim sekolah merupakan hasil dari media interaksi dalam organisasi sekolah.

iklim dan budaya sekolah yang kondusif mendorong setiap warga sekolah untuk bertindak dan melakukan sesuatu yang terbaik yang mengarah pada prestasi peserta didik yang tinggi 


\section{DAFTAR RUJUKAN}

Departemen Pendidikan Nasional, Pengembangan Iklim dan Budaya pembelajaran di Sekolah, 2007

Muhaimin, Manajemen Pendidikan Aplikasinya dalam Menyusun Rencana Pengembangan Sekolah/Madrasah, Cet. 4; Jakarta: Fajar Interpratama Offeset, 2012.

Mulyasa, Manajemen \& Kepemimpinan Kepala Sekolah, Cet.3; Jakarta: PT Bumi Aksara, 2013.

Saefullah, Manajemen Pendidikan Islam, Cet.1; Bandung: Pustaka setia, 2012.

Suhardan, Dadang,, Supervisi Profesioonal, Cet, III; Bandung: Alfabeta, 2010 . 